\title{
C4A Gene
}

National Cancer Institute

\section{Source}

National Cancer Institute. C4A Gene. NCI Thesaurus. Code C128857.

This gene plays a role in the progression of the classical complement pathway. 